\title{
Two new species of Myliocotyle (Monogenea: Monocotylidae) from the gills of Aetomylaeus maculatus and $A$. nichofii (Elasmobranchii: Myliobatidae) from Sarawak, Borneo, Malaysia
}

\author{
Leslie A. Chisholm ${ }^{1}$ and Ian D. Whittington ${ }^{1,2}$ \\ ${ }^{1}$ Marine Parasitology Laboratory, School of Earth and Environmental Sciences, The University of Adelaide, North Terrace, \\ Adelaide, South Australia 5005, Australia; \\ ${ }^{2}$ Monogenean Research Laboratory, Parasitology Section, The South Australian Museum, North Terrace, Adelaide, South \\ Australia 5000, Australia
}

Key words: Monogenea, Monocotylidae, Heterocotylinae, Myliocotyle, Myliobatidae, Aetomylaeus, taxonomy

\begin{abstract}
Myliocotyle borneoensis sp. n. and M. multicrista sp. n. (Monocotylidae: Heterocotylinae) are described from the gills of the mottled eagle ray, Aetomylaeus maculatus (Gray), and the banded eagle ray A. nichofii (Bloch et Schneider) (Myliobatidae), respectively, collected from the northern coast of Malaysian Borneo. These are the first monogeneans to be described on elasmobranchs from Borneo. The formerly monotypic Myliocotyle (for M. pteromylaei) was distinguished from other monocotylids by the distribution and morphology of the eight sclerotised dorsal haptoral accessory structures and the morphology of the male copulatory organ. However, we have determined that $M$. pteromylaei has ten structures on the dorsal surface of the haptor. Myliocotyle borneoensis is distinguished from $M$. pteromylaei by the morphology of the male copulatory organ and its accessory piece. Myliocotyle multicrista has 12 sclerotised dorsal haptoral accessory structures and a male copulatory organ with two accessory pieces. Additional sclerotised ridges across the ventral surfaces of each loculus (except the posterior-most pair) are also present in M. multicrista. The diagnosis for Myliocotyle is revised given our discovery of additional dorsal haptoral accessory structures in the type species and to accommodate other new characters of the two new species. Anterior secretions of Myliocotyle are discussed.
\end{abstract}

There are currently no published records of any metazoan parasite from any species of elasmobranch (sharks and rays) off Borneo. Preliminary data indicate that the diversity of elasmobranchs around Borneo is high and that many of them are new species (Fowler et al. 1999, Last and Stevens pers. comm.). Rays are host to a wide diversity of monogeneans that infect the skin, gills, nasal tissue, urogenital system and body cavity (Chisholm and Whittington 1998a, Whittington and Chisholm 2003). While the diversity of monogeneans on sharks appears to be lower (Whittington and Chisholm 2003), it is clear that the unexplored monogenean fauna of elasmobranchs from Borneo is likely to be extensive. Two six-week surveys were conducted throughout Malaysian Borneo in May/June of 2002 and 2003 as part of a large collaborative study funded by the United States National Science Foundation's (NSF) Biotic Surveys and Inventories Program to identify and chart the diversity of sharks and rays and their metazoan parasites. This paper describes two new species of monocotylid monogeneans belonging to the previously monotypic Myliocotyle Neifar, Euzet et Ben Hassine, 1999 from myliobatid rays.

\section{MATERIALS AND METHODS}

Every elasmobranch collected during the surveys was assigned a unique Borneo (BO) autopsy number. This number can be used to access additional host information on the Borneo elasmobranch survey database available on-line soon through www.tapeworms.org. One specimen (BO-22) of the mottled eagle ray, Aetomylaeus maculatus (Gray, 1834) (Rajiformes: Myliobatidae), was collected in June, 2002 and a second specimen (BO-178) in June, 2003 by local fishermen off Sematan (01 $48^{\prime} 00^{\prime \prime} \mathrm{N}, 1^{\circ} 9^{\circ} 46^{\prime} 00^{\prime}$ 'E), Sarawak, Borneo. Three specimens (BO-34, BO-37 and BO-59) of the banded eagle ray Aetomylaeus nichofii (Bloch et Schneider, 1801), were obtained from the local fish market in Mukah $\left(02^{\circ} 54^{\prime} 00^{\prime} ' \mathrm{~N}, 112^{\circ} 60^{\prime} 00^{\prime \prime} \mathrm{E}\right)$, Sarawak in June, 2002. Two additional specimens (BO-145, BO-180) of $A$. nichofii were collected off Sematan in June, 2003. P. Last, J. Stevens and G. Yearsley identified the hosts. Gills from rays collected in 2003 were fixed in formalin and later transferred to ethanol before examination; no parasites were found. Freshly dissected gills from each ray collected in 2002 were examined for monogeneans soon after capture. Dead parasites, recovered from the gills, were fixed unflattened in $4 \%$ buffered neutral formalin. Worms were then transferred to $70 \%$ ethanol, stained with Semichon's carmine, dehydrated in an ethanol series, cleared in cedarwood oil and mounted in Canada balsam. Preserved adult monogeneans were examined using a compound microscope equipped with phase contrast or Nomarski optics and drawings were made with the aid of a drawing tube. Measurements of all specimens were made using a computerised digitising system similar to that described by Roff and Hopcroft (1986). All measurements are given in $\mu \mathrm{m}$ as the mean followed in parentheses by the range and the number of

Address for correspondence: L. Chisholm, Marine Parasitology Laboratory, School of Earth and Environmental Sciences, Darling Building DP 418, The University of Adelaide, North Terrace, Adelaide, South Australia 5005, Australia. Phone: ++61 88207 7302; Fax: ++61 882077222 ; E-mail: chisholm.leslie@saugov.sa.gov.au 
structures measured. Body length measurements exclude the haptor; measured from anterior end to point where body joins haptor. Measurements of the curved male copulatory organ follow the curve. Haptoral terminology follows that of Chisholm and Whittington (1996).

For comparative purposes, four paratypes (1999.1.15.10 13) of Myliocotyle pteromylaei Neifar, Euzet et Ben Hassine, 1999, were obtained from The Natural History Museum (BMNH), Cromwell Road, London, SW7 5BD, UK. The holotype of each new species described here is deposited in the Muzium Zoologi Universiti Malaya (MZUM), Institute of Biological Sciences, Universiti Malaya, Kuala Lumpur 50603, Malaysia (contact: S. Lim). Paratypes are deposited in the MZUM, the Sarawak Biodiversity Centre (SBC) KM20 Jalan Borneo Heights, Semengoh Locked Bag No 3032, 93990 Kuching, Sarawak, Malaysia (contact: M. Naming), the Australian Helminthogical Collection of The South Australian Museum (SAMA), North Terrace, Adelaide, South Australia 5000, Australia (contact: I. Whittington) and The United States National Parasite Collection (USNPC), Beltsville, MD 20705, USA (contact: E. Hoberg).

\section{RESULTS}

$\mathrm{H}$ e $\mathrm{t}$ e $\mathrm{r}$ o c o t y $1 \mathrm{i} \mathrm{n}$ a e Chisholm, Wheeler et Beverley-Burton, 1995

\section{Myliocotyle Neifar, Euzet et Ben Hassine, 1999}

\section{Amended generic diagnosis}

Monocotylidae, Heterocotylinae. Haptor divided by septa into one central and eight peripheral loculi. Marginal valve present. Single hamulus associated with each posterolateral radial septum. Sclerotised sinuous ridge present on all septa; single ridge on outer ring septum, posterior half of inner ring septum and on posterior and posterolateral radial septa; two ridges on lateral septa and anterior half of inner ring septum; three ridges on anterolateral and anterior radial septa. In $M$. multicrista sp. $\mathrm{n}$. (see below) at least four additional lightly sclerotised ridges cross ventral surface of each loculus except central loculus and posterior-most pair. Dorsal surface of haptor armed with ten or 12 sclerotised accessory structures; three associated with each posterior-most loculus, two or three associated with each posterolateral loculus. Eyespots present as dorsally distributed, dispersed pigment granules. Anterior end with distinct frontal lappet where anterior gland ducts open. Male copulatory organ sclerotised, tubular; one or two sclerotised accessory pieces present. Sclerotised structure, probably spermatophore, often present in vagina.

Remarks. Neifar et al. (1999) defined Myliocotyle with eight sclerotised accessory structures on the dorsal surface of the haptor; three associated with the dorsal surface of each posterior-most loculus and one associated with each posterolateral loculus. However, we reexamined type material from the BMNH and found that there are two sclerotised structures associated with the dorsal surface of each posterolateral loculus (Fig. 1).

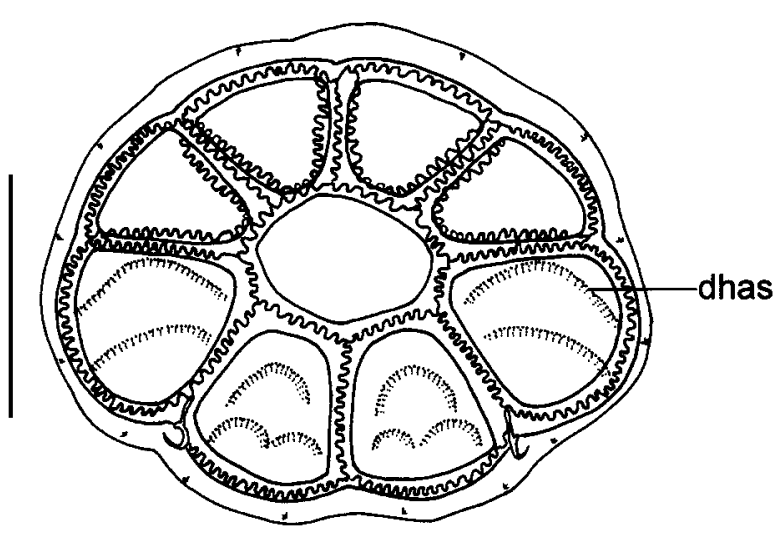

Fig. 1. Haptor of Myliocotyle pteromylaei Neifar, Euzet et Ben Hassine, 1999 showing number and distribution of sclerotised dorsal haptoral accessory structures (dhas). Drawn from paratype BMNH 1999.1.15.10-13 (slide with single specimen). Scale bar $=100 \mu \mathrm{m}$.

Therefore, there is a total of ten structures on the dorsal surface of the haptor of $M$. pteromylaei. The diagnosis has been amended to accommodate this change and to include other new characters arising from the description of the following two new species.

Neifar et al. (1999) noted in their discussion that pseudosepta were present in the posterolateral, lateral and anterior loculi of $M$. pteromylaei, but that they were difficult to see. The presence of pseudosepta was not included in their generic diagnosis of Myliocotyle or illustrated in their figures. We could not see pseudosepta clearly in the specimens we examined and therefore do not include this character in our generic diagnosis.

Myliocotyle borneoensis sp. n.

Figs. 2-4

Description. Heterocotylinae sensu Chisholm and Whittington (1996). Description and measurements based on nine sexually mature specimens. Body 923 (663-1129, $\mathrm{n}=8)$ long, $196(124-240, \mathrm{n}=9)$ wide at level of ovary (Fig. 2). Haptor oval, 235 (152-391, $\mathrm{n}=$ 9) long and $342(255-443, \mathrm{n}=9)$ wide; divided by septa into one central and eight peripheral loculi (Fig. 2). Hamuli (Fig. 3) 34 (31-39, n=7) long, located in outer ring septum associated with each posterolateral radial septum. Fourteen hooklets distributed symmetrically in marginal valve as illustrated (Fig. 2). Single sclerotised ridge on posterior half of inner ring, outer ring and on posterior and posterolateral radial septa; two ridges present on anterior half of inner ring septum and lateral septa; three ridges on anterolateral and anterior radial septa (Fig. 2). Ten sclerotised dorsal haptoral accessory structures; three associated with each posterior-most loculus, two associated with each posterolateral loculus (Fig. 2).

Mouth ventral, subterminal; surrounded by highly muscular region (Fig. 2). Frontal lappet extends anteri- 


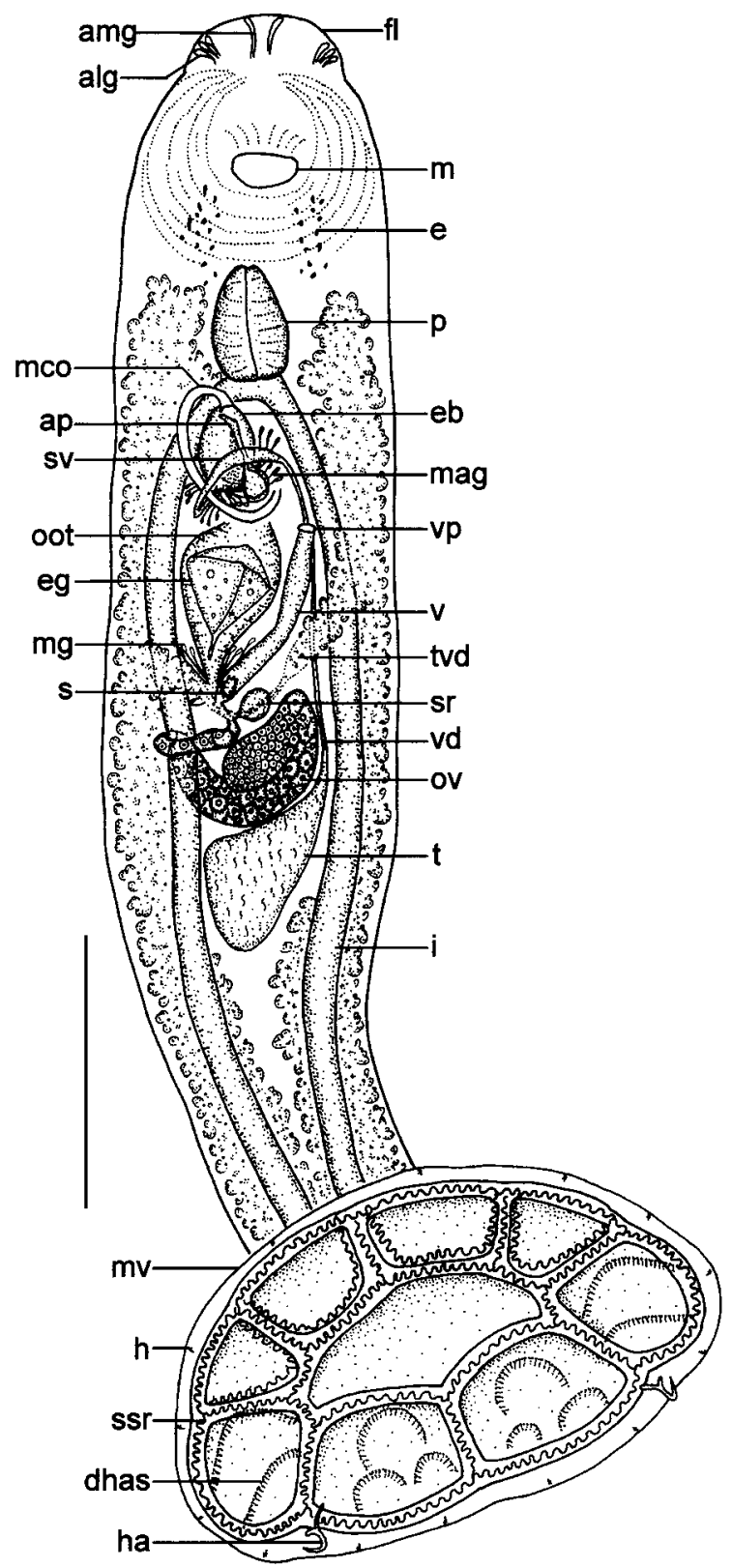

Fig. 2. Myliocotyle borneoensis sp. n., whole animal, ventral view. Abbreviations: alg - anterolateral gland duct ending; amg - anteromedian gland duct ending; ap - accessory piece; dhas - dorsal haptoral accessory structure; e - eyespot; eb ejaculatory bulb; eg - egg; $\mathrm{fl}$ - frontal lappet; $\mathrm{h}$ - hooklet; ha hamulus; $\mathrm{i}$ - intestine; $\mathrm{m}$ - mouth; mag - male accessory glands; mco - male copulatory organ; $\mathrm{mg}$ - Mehlis' glands; mv - marginal valve; oot - oötype; ov - ovary; $\mathrm{p}$ - pharynx; $\mathrm{s}$ - spermatophore; sr - seminal receptacle; ssr - sclerotised sinuous ridge; $\mathrm{sv}$ - seminal vesicle; $\mathrm{t}$ - testis; $\mathrm{tvd}$ - transverse vitelline duct; $\mathrm{v}$ - vagina; vd - vas deferens; $\mathrm{vp}$ - vaginal pore. Scale bar $=200 \mu \mathrm{m}$.

orly from muscular region. One pair of anteromedian gland duct endings and three pairs of anterolateral gland duct endings observed at anterior end of frontal lappet (Fig. 2); type of secretion could not be determined. Eye-

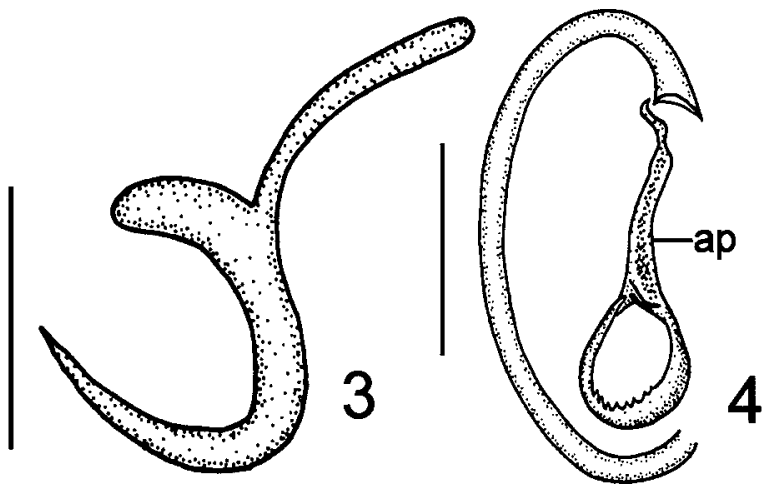

Figs. 3, 4. Myliocotyle borneoensis sp. n. Fig. 3. Hamulus. Fig. 4. Male copulatory organ with single sclerotised accessory piece. Scale bars: Fig. $3=20 \mu \mathrm{m}$; Fig. $4=50 \mu \mathrm{m}$.

spots as highly dispersed pigment granules distributed anterior and dorsal to pharynx (Fig. 2). Pharynx 82 (65$99, \mathrm{n}=9)$ long, $53(37-69, \mathrm{n}=9)$ wide. Intestinal caeca without diverticula, run to posterior margin of body proper, ending blindly.

Testis single. Vas deferens arises from left side of testis, runs anteriorly dorsal to vagina. Vas deferens curves ventral to ejaculatory bulb and inflates to form seminal vesicle then narrows, entering ejaculatory bulb posteriorly (Fig. 2). Ejaculatory bulb $69(61-77, \mathrm{n}=9)$ long, $50(39-61, \mathrm{n}=9)$ wide; male accessory glands present. Male copulatory organ sclerotised curved tube $194(175-210, \mathrm{n}=9)$ long (Figs. 2, 4). Unique sclerotised accessory piece present (Figs. 2, 4).

Ovary loops right intestinal caecum dorsoventrally and forms oviduct. Oviduct receives common vitelline duct and duct from seminal receptacle $18(14-22, \mathrm{n}=5)$ diameter. Ovovitelline duct enters oötype. Oötype 97 $(80-117, \mathrm{n}=7)$ long. Mehlis' glands present. Vaginal pore ventral, on left side of body at level of anterior part of oötype. Sclerotised spermatophore (Fig. 2) (see Discussion) $26(24-30, \mathrm{n}=5)$ in diameter observed proximally in vagina of five specimens. Vitellarium extends from level of anterior portion of pharynx to posterior portion of body proper. Transverse vitelline duct at level of anterior portion of seminal receptacle; common vitelline duct joining oviduct. Egg tetrahedral (Fig. 2); side length $59(46-68, \mathrm{n}=7$ ) (measured within oötype of specimens).

T y p e h o s t: Aetomylaeus maculatus (Gray, 1834) (Elasmobranchii, Myliobatidae).

$\mathrm{S}$ i t e o n h o s t: Gills, specimens found between secondary lamellae.

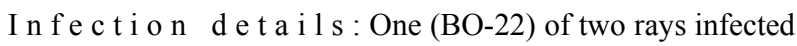
(50\% prevalence) with nine parasites.

T y p e 1 o c a 1 i t y : Sematan, Sarawak, Borneo, Malaysia (01 ${ }^{\circ} 48^{\prime} 00^{\prime \prime} \mathrm{N}, 109^{\circ} 46^{\prime} 00^{\prime}$ 'E).

$\mathrm{E}$ t $\mathrm{y} \mathrm{m}$ o $\log \mathrm{y}$ : The species name is derived from the island locality. 
M a t e r i a 1 e x a m i n e d : Holotype MZUM(P) 50(h); 2 paratypes MZUM(P) 51 and 52(p); 1 paratype SBC-P00001; 2 paratypes SAMA AHC 28631 and 28632; 3 paratypes USNPC 94875.

Remarks. Myliocotyle borneoensis can be distinguished from the other species in the genus by the morphology of the male copulatory organ and its accessory piece.

\section{Myliocotyle multicrista sp. n.}

Figs. 5-7

Description. Heterocotylinae sensu Chisholm and Whittington (1996). Description and measurements based on four sexually mature specimens. Body 1512 (1309-1738, n = 3) long, $401(316-495, \mathrm{n}=4)$ wide at level of ejaculatory bulb (Fig. 5). Haptor oval, 341 $(282-384, \mathrm{n}=3)$ long, $509(428-650, \mathrm{n}=3)$ wide; divided by septa into one central and eight peripheral loculi (Fig. 5). Hamuli (Fig. 6) $34(\mathrm{n}=1)$ long, located in outer ring septum associated with each posterolateral radial septum. Fourteen hooklets distributed symmetrically in marginal valve as illustrated (Fig. 5). Single sclerotised ridge on posterior half of inner ring, outer ring and on posterior and posterolateral radial septa; two ridges present on anterior half of inner ring septum and lateral septa; three ridges on anterolateral and anterior radial septa (Fig. 5). A minimum of four to five additional, lightly sclerotised ridges cross ventral surface of each loculus except central loculus and posterior-most pair (Fig. 5). Twelve sclerotised dorsal haptoral accessory structures; three associated with each posteriormost loculus, three associated with each posterolateral loculus (Fig. 5).

Mouth ventral, subterminal; surrounded by highly muscular region (Fig. 5). Frontal lappet extends anteriorly from muscular region. Gland duct endings observed at anterior end of frontal lappet (Fig. 5); exact number of duct openings and type of secretion not determined. Eyespots as highly dispersed pigment granules distributed anterior and dorsal to pharynx. Pharynx 114 $(90-134, \mathrm{n}=4)$ long, $71(56-86, \mathrm{n}=4)$ wide. Intestinal caeca without diverticula, run to posterior margin of body proper, ending blindly.

Testis single. Vas deferens arises from left side of testis, runs anteriorly dorsal to vagina. Vas deferens curves ventral to ejaculatory bulb and inflates to form seminal vesicle then narrows, entering ejaculatory bulb posteriorly (Fig. 5). Ejaculatory bulb 114 (97-143, n = 4) long, $86(69-108, \mathrm{n}=4)$ wide; male accessory glands present. Male copulatory organ (Figs. 5, 7) sclerotised, curved tube $364(338-394, \mathrm{n}=4)$ long. Small sclerotised acces-sory piece $37(35-42, n=4)$ long, associated with proximal end of male copulatory organ; additional lightly sclerotised accessory structure also associated with almost entire length of male copulatory organ (Fig. 7).

Ovary loops right intestinal caecum dorsoventrally and forms oviduct. Oviduct receives common vitelline

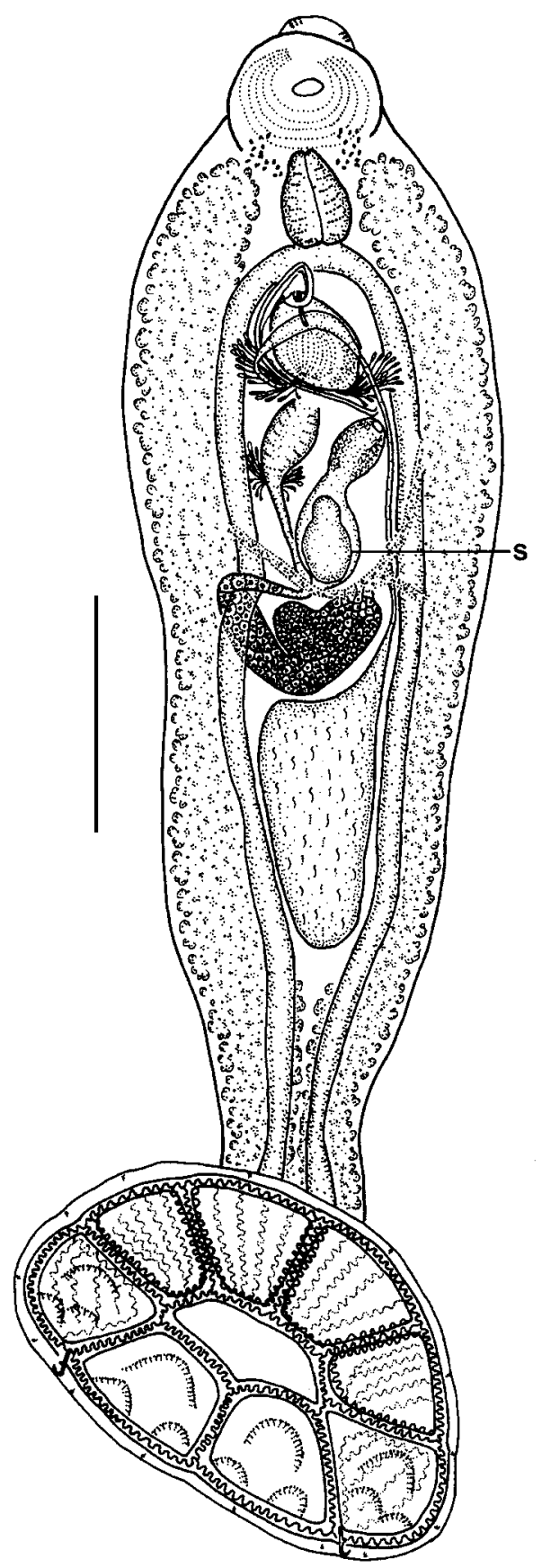

Fig. 5. Myliocotyle multicrista sp. n., whole animal, ventral view. Note additional lightly sclerotised ridges on ventral surface of loculi and spermatophore (s) in vagina. Scale bar $=$ $300 \mu \mathrm{m}$.

duct. Seminal receptacle not seen. Ovovitelline duct enters oötype. Oötype $97(80-107, n=4)$ long. Mehlis' glands present. Vaginal pore ventral, on left side of body at level of anterior part of oötype. Vagina divided into two sections; distal part glandular. Large sclerotised structure, presumably a spermatophore, $87(73-106, \mathrm{n}=$ 3) long, $64(58-71, n=3)$ wide, in proximal region of 

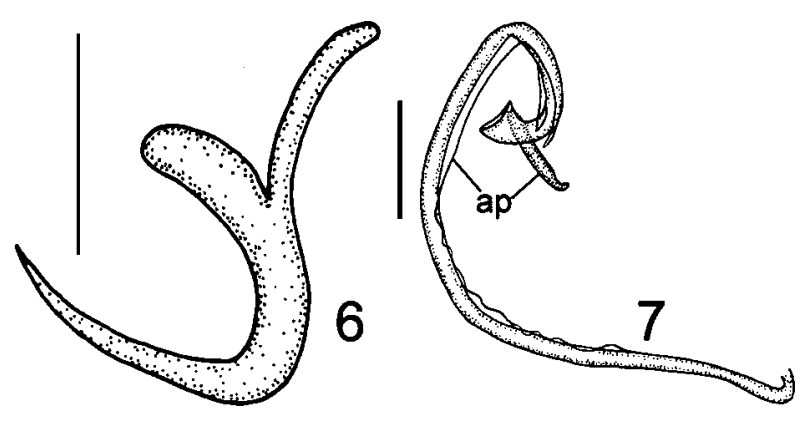

Figs. 6, 7. Myliocotyle multicrista sp. n. Fig. 6. Hamulus. Fig. 7. Male copulatory organ with two sclerotised accessory pieces. Scale bars: Fig. $6=20 \mu \mathrm{m}$; Fig. $7=50 \mu \mathrm{m}$.

vagina of all specimens (Fig. 5). Vitellarium extends from level of anterior portion of pharynx to posterior portion of body proper. Transverse vitelline duct at level of anterior portion of ovary; common vitelline duct joining oviduct. Egg tetrahedral; side length 67 (61-75, $\mathrm{n}=4$ ) (measured within oötype of specimen).

$\mathrm{T}$ y p e h o s t : Aetomylaeus nichofii (Bloch et Schneider, 1801) (Elasmobranchii, Myliobatidae).

S i t e o n hos t: Gills, specimens found between secondary lamellae.

I $\mathrm{n}$ f e c t i o n d e t a i $1 \mathrm{~s}$ : One (BO-34) of five rays infected (prevalence 20\%) with four parasites.

T y p e 1 o c a 1 i t y : Mukah, Sarawak, Borneo, Malaysia (02 $\left.54^{\prime} 00^{\prime \prime} \mathrm{N}, 112^{\circ} 60^{\prime} 00^{\prime \prime} \mathrm{E}\right)$.

$\mathrm{E}$ t y $\mathrm{m} \mathrm{ol}$ o g y : The species name is derived from the Latin words multi (many) and crista (ridge) which refers to the many lightly sclerotised ridges associated with the ventral surface of the loculi.

M a t e r i a 1 e x a m i n e d: Holotype MZUM(P) 53(h), 1 paratype SBC-P-00002; 1 paratype SAMA AHC 28633; 1 paratype USNPC 94876.

Remarks. Myliocotyle multicrista can be distinguished from the other members of the genus by the number (12) of sclerotised dorsal haptoral accessory structures and by the additional lightly sclerotised sinuous ridges crossing the ventral surface of each loculus except the central loculus and the posterior-most pair. The morphology of the male copulatory and its two accessory pieces is also unique.

\section{DISCUSSION}

There are now three species in Myliocotyle (Monocotylidae: Heterocotylinae) including M. pteromylaei Neifar, Euzet et Ben Hassine, 1999, M. borneoensis and M. multicrista. All species have been reported from the gills of myliobatid rays. Myliocotyle borneoensis and $M$. multicrista are the first monogeneans to be recorded from rays collected in waters around Borneo.

Neifar et al. (1999) described the haptor of M. pteromylaei with eight sclerotised dorsal haptoral accessory structures. The single accessory structure associated with each posterolateral loculus was illustrated as curving sharply through approximately $180^{\circ}$. However close examination of four type specimens revealed that there are actually two separate dorsal structures (Fig. 1) instead of one in each posterolateral loculus. Neifar et al. (1999) mention that they used scanning electron microscopy (SEM) to count the number of sinuations of the septal ridges in $M$. pteromylaei, but no micrographs of the ventral or dorsal haptoral surfaces, which would confirm the morphology of the dorsal structures, were provided.

We have adopted a conservative approach by including M. multicrista in Myliocotyle. The number of dorsal haptoral accessory structures differs from the other two species but this variability also occurs in other Monocotylidae. Members of Decacotyle Young, 1967 possess two, four, eight or 12 dorsal haptoral accessory structures (see Chisholm and Whittington 1998b). The lightly sclerotised ridges crossing the ventral surface of the haptoral loculi have not been described in any other monocotylid and could not been seen in the other species of Myliocotyle despite careful examination by us. These additional ventral sclerotised ridges could not be seen using Nomarski optics and were only visible using phase contrast. With only four specimens available, we could not confirm whether the number and path of the ridges was consistent among specimens. SEM of additional material would be ideal to resolve this question. It is possible that these ridges are associated with pseudosepta, which were described in M. pteromylaei (see Neifar et al. 1999), but we could find no evidence of pseudosepta in M. multicrista. Again, SEM would help resolve this. Other features of $M$. multicrista such as the general morphology of the anterior region, hamuli, male copulatory organ, vagina, ovary and the presence of spermatophores are consistent with those of $M$. pteromylaei and M. borneoensis. Therefore we believe it unnecessary to erect a new genus based on this single character. The function of these additional ridges is unknown. It is possible that they provide additional purchase and help the parasite maintain secure attachment to the gills of the host.

Sclerotised structures, assumed to be spermatophores, have been observed in the vagina of all three Myliocotyle species. The "spermatophore", seen in the proximal region of the vagina of $M$. borneoensis, differs morphologically from those observed in the other two Myliocotyle species and from those described in other monocotylids (e.g. Dendromonocotyle species; see Chisholm et al. 2001). Accessory sclerites have been observed in the vagina of other monocotylids (e.g. some species of Heterocotyle and Monocotyle; see Chisholm and Whittington 1996, Chisholm 1998, respectively) and therefore we considered that perhaps the structure in M. borneoensis was an accessory vaginal sclerite. However, when accessory vaginal sclerites are recorded, 
they are present in each mature specimen. Since the sclerotised structure in the vagina of $M$. borneoensis was only present in five of nine mature adult specimens, we assume it is a spermatophore.

Neifar et al. (1999) question whether the term "accessory piece" is appropriate to describe the additional structures associated with the male copulatory organ proper. We agree that suitable terminology is difficult to determine since the role these "accessory pieces" play in the function of the male copulatory organ cannot be ascertained without observations of mating. Currently, all species in Myliocotyle have at least one additional structure associated with the male copulatory organ, which we currently call an "accessory piece". In $M$. multicrista, there appear to be two accessory pieces: one narrow and heavily sclerotised structure associated with the proximal end of the male copulatory organ and another lightly sclerotised structure which is similar to that described by Neifar et al. (1999) for M. pteromylaei. This runs almost the entire length of the male copulatory organ (Fig. 7).

The anterior end of Myliocotyle is distinctive. The area around the mouth is strongly muscular and there appears to be a separate frontal lappet onto which the anterior gland ducts open. Examination of the anterior secretions to confirm their distribution and content is best done using live material under phase contrast microscopy, but unfortunately live material of $M$. borneoensis and M. multicrista was unavailable to us. SEM can also be useful to confirm the number of anterior gland duct openings. Neifar et al. (1999) described and illustrated the anterior gland system in $M$. pteromylaei from specimens mounted in Berlese's medium. A single duct arises from each of the two anteromedian glands of M. pteromylaei. Fourteen to 16 gland duct openings arising from ducts of the anterolateral glands are also apparently present on either side of the head of $M$. pteromylaei (cf. fig. 6, Neifar et al. 1999). However, in the $M$. pteromylaei paratypes we examined (stained with acetocarmine), the number of openings was highly variable (3-13 on each side of head). We only observed a maximum of three anterolateral gland duct endings on either side of the head of M. borneoensis and M. multicrista. However, we could not see the glands from which these ducts originated nor confirm the exact number of openings. Because these parasites were dead when we recovered them, it is possible that the secretions had been exhausted rendering the glands, their ducts and openings difficult to see in fixed material. The arrangement of anterior gland duct openings is generally consistent within each genus in the Heterocotylinae (see Chisholm and Whittington 1996 for Heterocotyle, Chisholm and Whittington 1997 for Neoheterocotyle) and is likely a useful phylogenetic character (Whittington and Cribb 2001). Therefore the arrangement of anterior glands and the number of openings requires confirmation in Myliocotyle.

The type of secretion produced by the anterior glands is also of considerable interest both functionally and phylogenetically (Whittington and Cribb 2001). Neifar et al. (1999) state that the anteromedian gland and anterolateral glands contain granular secretions and no glands containing needle-like secretions were observed. We were unable to determine the type of anterior secretion in M. borneoensis and M. multicrista. Members of the Heterocotylinae usually have both needlelike and granular anterior secretions (Chisholm and Whittington 1996, Cribb et al. 2001, Cribb and Whittington 2004) and therefore the apparent presence of only a single type of secretion is unusual and worth further study.

Acknowledgements. This study would not have been possible without the assistance of the other members of the international collecting team including: J. Caira (University of Connecticut, USA), K. Jensen (University of Kansas, USA), G. Naylor (Iowa State University, USA), P. Last, J. Stevens and G. Yearsley (CSIRO Marine Research, Australia). We also thank Mabel Manjaji, Annadel Cabanban and Justine Tampuling from the University of Malaysia, Sabah for their assistance. We are indebted to Annie Lim Pek Khiok, George Chong and Albert Gambang of the Fisheries Research Institute, Kuching, Sarawak for help which extended far beyond the call of duty. We thank E. Harris (BMNH) for the loan of type material. The Sarawak Biodiversity Centre, Borneo was instrumental in helping us obtain the necessary permits; work in Sarawak was carried out under collecting permit SBC-RP0052a-JNC, export permit SBC-EP-0027-JNC and the Malaysian Economic Planning Unit permit UPE:40/200/19 SJ.924. This study was supported with funds from the National Science Foundation's Biotic Surveys and Inventories Program (award no. DEB-103640).

\section{REFERENCES}

CHISHOLM L.A. 1998: A revision of Monocotyle Taschenberg, 1878 (Monogenea: Monocotylidae) with description of three new species from Australia. J. Nat. Hist. 32: $1259-1290$

CHISHOLM L.A., WHITTINGTON I.D. 1996: A revision of Heterocotyle (Monogenea: Monocotylidae) with a description of Heterocotyle capricornensis n. $\mathrm{sp}$. from Himantura fai (Dasyatididae) from Heron Island, Great Barrier Reef, Australia. Int. J. Parasitol. 26: 1169-1190.
CHISHOLM L.A., WHITTINGTON I.D. 1997: A revision of Neoheterocotyle (Monogenea: Monocotylidae) with descriptions of the larvae of $N$. rhinobatis and N. rhynchobatis from Heron Island, Great Barrier Reef, Australia. Int. J. Parasitol. 27: 1041-1060.

CHISHOLM L.A., WHITTINGTON I.D. 1998a: Morphology and development of the haptors among the Monocotylidae (Monogenea). Hydrobiologia 383: 251-261.

CHISHOLM L.A., WHITTINGTON I.D. 1998b: Revision of Decacotylinae Chisholm, Wheeler \& Beverley Burton, 
1995 (Monogenea: Monocotylidae) including the synonymy of Papillicotyle Young, 1967 with Decacotyle Young, 1967 and a description of a new species from Australia. Syst. Parasitol. 41: 9-20.

CHISHOLM L.A., WHITTINGTON I.D., KEARN G.C. 2001: Dendromonocotyle colorni $\mathrm{sp} . \mathrm{n}$. (Monogenea: Monocotylidae) from the skin of Himantura uarnak (Dasyatididae) from Israel and a new host record for D. octodiscus Hargis, 1955 from the Bahamas. Folia Parasitol. 48: 15-20.

CRIBB B.W., GOULD R., WHITTINGTON I.D. 2001: A comparison of anterior adhesive areas and secretions in Troglocephalus rhinobatidis and Neoheterocotyle rhinobatidis (Monogenea: Monocotylidae) from the gills of the shovelnose ray, Rhinobatos typus (Rhinobatidae). Aust. J. Zool. 49: 577-587.

CRIBB B.W., WHITTINGTON I.D. 2004: Anterior adhesive areas and adjacent secretions in the parasitic flatworms Decacotyle lymmae and D. tetrakordyle (Monogenea: Monocotylidae) from the gills of stingrays. Invertebr. Biol. 123: 68-77.
FOWLER S.L., MANJAJI M.B., CAVANAGH R.D., COMPAGNO L.J.V., MYCOCK S.G., LAST P.R. 1999: Elasmobranch biodiversity, conservation and management in Sabah (Malaysia). In: B. Séret and J.-Y. Sire (Eds.), Proceedings of the 5th Indo-Pacific Fish Conference Nouméa, pp. 257-269.

NEIFAR L., EUZET L., BEN HASSINE O.K. 1999: Myliocotyle pteromylaei gn. et sp. n. (Monogenea: Monocotylidae) parasite branchial de Pteromylaeus bovinus (Euselachii, Myliobatidae) en Tunisie. Parasite 6: 323-327.

ROFF J.C., HOPCROFT R.R. 1986: High precision microcomputer based measuring system for ecological research. Can. J. Fish. Aquat. Sci. 43: 2044-2048.

WHITTINGTON I.D., CHISHOLM L.A. 2003: Diversity of Monogenea from Chondrichthyes: do monogeneans fear sharks? In: C. Combes and J. Jourdane (Eds.), Taxonomie, Écologie et Évolution des Métazoaires Parasites. (Livre hommage à Louis Euzet). Tome 2. PUP Perpignan, France, pp. 339-363.

WHITTINGTON I.D., CRIBB B.W. 2001: Adhesive secretions in the Platyhelminthes. Adv. Parasitol. 48: 101-224.

Accepted 28 June 2004 